Araştırma Makalesi

Research Article

Geliş Tarihi: 09.04.2019

Received: 09.04.2019

Kabul Tarihi: 01.07.2019

Accepted: 01.07.2019

Yazar, F., \& Özutku, H. (2019). Psikolojik sermayenin örgütsel bağlılık üzerindeki etkisine yönelik bir araştırma. KOCATEPEIIIBF Dergisi, Aralık 2019, 21(2), 70-81.

\title{
PSİKOLOJİK SERMAYENİN ÖRGÜTSEL BAĞLILIK ÜZERİNDEKİ ETKİSİNE YÖNELİK BİR ARAŞTIRMA
}

\author{
FUNDA YAZAR ${ }^{1}$, HATICE ÖZUTKU ${ }^{2}$
}

\section{Öz}

Araştırma kapsamı giderek genişleyen psikolojik sermaye kavramı, örgütlerin önem verdikleri konular arasına girmiştir. Örgütlerin sürdürülebilirliği için önemli olan örgütsel bağlılık konusunu etkileyen olumlu ve olumsuz unsurlar araştırılmakta ve örgütler bulunan olumlu unsurların geliştirilmesi için çaba sarf ederken, olumsuz unsurlar için de çözüm arayışına girmektedirler. Örgütsel bağlılığı olumlu etkileyeceği düşünülen çalışanların psikolojik sermaye düzeyleri araştırmanın içeriğini oluşturmaktadır. Araştırmada psikolojik sermaye kavramının boyutları olan öz yeterlilik, umut, psikolojik dayanıklılık ve iyimserlik düzeylerinin örgütsel bağlılığa etkisi analiz edilmiş ve bu amaçla bir kamu kurumunda uygulama yapılarak sonuçlar ortaya konmuştur. 157 kişinin katıldığı araștırmadan elde edilen verilerin analiz sonuçlarına göre, çalışanların psikolojik sermaye düzeyleri örgütsel bağlılıklarını pozitif yönde etkilemektedir.

Anahtar Kelimeler: Örgütsel Bağlılık, Psikolojik Sermaye, Öz Yeterlilik, Umut, Psikolojik Dayanıklılık, İyimserlik.

JEL Kodları: M1, M14.

\section{A RESEARCH ON THE EFFECT OF PSYCHOLOGICAL CAPITAL ON ORGANIZATIONAL COMMITMENT}

\begin{abstract}
The concept of psychological capital has expanded its research increasingly and also has become one of the issues which organizations care about. The negative and positive issues affecting organizational commitment which is important for organizations' sustainability are searched and while organizations are striving for the development of positive elements, they are seeking solutions for negative ones. The purpose of this research is to determine employees' psychological capital levels which is thought to affect organizational commitment positively. In this research, the effects of self-efficacy, hope, resilience and optimism levels, which are the dimensions of psychological capital, on organizational commitment were analized and the results are determined by applying them in a public institution. According to the results of the data which obtained from the study with 157 participants, employees' psychological capital levels affect their organizational commitment positively.
\end{abstract}

Keywords: Organizational Commitment, Psychological Capital, Self-Efficacy, Hope, Optimism, Resilience.

JEL Codes: M1, M14.

\footnotetext{
1 Doktora Öğrencisi, Afyon Kocatepe Üniversitesi, Sosyal Bilimler Enstitüsü, İşletme Ana Bilim Dall, fundasomuncu@yahoo.com- ORCID: 0000-0002-5434-9983.

2 Prof. Dr., Afyon Kocatepe Üniversitesi, İktisadi ve İdari Bilimler Fakültesi İșletme Bölümü, hozutku@aku.edu.tr ORCID: 0000-0003-0425-4967.
} 


\section{GíRiş}

Bireylerin zihinsel sağlıkları için yapılan çalışmaların, onların gücüne inanmaktan uzaklaştığının, zor yaşantı ve koșulların olumsuz etkilerini gidermekte yetersiz kaldığının anlaşılması ile birlikte, psikolojide olumluya odaklanmayı esas alan yeni bir anlayış yaygınlaşmaya başlamıştır. Bu anlayış Seligman (2000) tarafından pozitif psikoloji olarak adlandırılmaktadır (Ergüner Tekinalp ve Işık Terzi, 2015:1). Pozitif psikoloji, bireylerin sahip oldukları güçlü yanlarının olduğunu dikkate alarak bu güçlü yönleri geliştirmeye odaklanmanın ruh sağlığını korumada ve uyum bozukluklarını gidermede en etkili yaklaşım olduğunu vurgulayan modern bir yaklaşımdır.

Fredrickson, 2001 yılında yaptığı çalışmasında, problemlerinin ve kendilerinin olumlu yanlarını görmenin çalışanların çözüm bulma yönünde cesaretlendireceğini belirtmiştir (Eryılmaz, 2013:7). Çalışanların olumlu duyguları deneyimlemesinin onların yaşama bağlanmalarında ve pek çok faaliyeti gerçekleştirmelerinde de önemli rolü vardır. Çalışanlara ilgi gösterilmesi onların bir şeyleri açılklamaya ve yeni bilgiler elde etmelerine yardımcı olmaktadır. Benzer şekilde, bireyler bașarılı olduklarında kendileriyle gurur duymaktadırlar. Bu gurur duygusuyla daha büyük başarılar elde etmeye yönelmektedirler (Eryılmaz, 2013:8). Bu tür olumlu duygular için geliştirilen Genişletme ve İnşa Etme Teorisi (Fredrickson 2001:221) pozitif duyguların hayatın her alanında olumlu etkilere sahip olduğunu ifade etmektedir. Bu teoride pozitif duyguların dikkati genişleteceği, bütünü görmeye yardımcı olacağını ve yaşantıyı kolaylaştıracağı iddia edilmektedir. Psikolojik sermaye ve örgütsel bağllık arasındaki ilişki irdelenirken genişletme ve inşa etme teorisinin etkisinden söz etmek mümkündür. Teorinin değindiği pozitif duygulara odaklanma psikolojik sermayenin değindiği olumlu duyguların bireye katkısı noktasını açılklamada yardımcı olmaktadır. Bireye katkısı olan bu olumlu duygu hallerinin aynı zamanda örgüte de kazandıracakları olacaktır.

Psikolojik sermaye kavramı pozitif psikoloji ve pozitif örgütsel davranış yaklaşımlarında ortaya çıkan bir kavramdır. Pozitif psikoloji temelinde bakıldığında, psikolojik sermaye çalışanların örgüt yaşantılarında umutlu, mutlu ve iyimser olmaları durumunda örgüte daha çok katkı sağlayacakları noktasına dikkat çeken bir kavram olarak incelenmekte ve araștırmalara konu olmaktadır. Bu durum örgüt performansını artırma konusunda dikkat çeken bir konu olan örgütsel bağllık konusuyla ilişkilendirilebilir olması sebebiyle, araştırmanın amacını oluşturmaktadır. Hem mutlu hem de örgüte bağlı çalışanlar örgütün başarısı için istenen bir durumdur. Psikolojik sermayenin kapsamını yaşananların olumlu yönde algılanması ve çalışanın bunu geliştirebilir görmesi oluşturmaktadır. Psikolojik sermaye çalışanların verimli olmak amacıyla örgütsel ortamda başarılı olmaları için gereken yeteneklerinin önemine değinmektedir. Örgütsel bağlllık örgütle uyum içerisinde çalışma, örgütün başarısı için istekli olma ve sorumlukları yerine getirme gibi konularda çalışanları yönlendirmesi açısından önemli bir konudur. Psikolojik sermaye düzeyleri geliştirilen çalışanların örgüte olan bağllıklarının da artacağı, bağlılığın artışı ile örgüt performansının da gelişeceği düşünülmektedir.

Psikolojik sermayenin boyutları olarak ele alınan iyimserlik, umut, öz yeterlilik ve psikolojik dayanıklılık boyutlarının çalışanların örgütsel bağllıklarına etki edip etmediği, etki ediyorsa hangi seviyelerde etkilediği kamu sektöründe faaliyet gösteren bir kurumda araştırllmak istenmiştir. Günümüzde özel sektörde olduğu kadar artık kamu sektöründe de çalışanların niteliklerini artırmaları ve alternatif iş fırsatlarını takip etmeleri sebebiyle işten ayrılmalar meydana gelmekte ya da çalışanın isteksizliği nedeniyle örgüt performanslarında düşüşler yaşanmaktadır. Ülkenin gelişme ihtiyacını sadece özel sektör değil kamu sektöründe faaliyet gösteren kurumlar da karşılamaktadır. Özellikle hizmet alımlarının fazla olduğu durumlarda hizmetin aksaması ya da hızla ilerlemesi çalışanlara bağlıdır. Bu sebeplerle psikolojik sermaye boyutlarının kamu çalışanlarının örgütsel bağlılığı üzerinde anlamlı bir etkisinin olup olmadığı kamu çalışanlarından oluşan bir örneklemde araştırılmıştır.

Çalışmanın tasarımında kavramsal çerçeve ortaya konulduktan sonra psikolojik sermaye ve örgütsel bağlılık arasındaki ilişkiye yönelik önceki çalışmaların bulguları verilerek araştırmanın hipotezleri ifade edilmiştir. Araştırmanın örneklemi ve araştırmada kullanılan ölçekler ilgili bilgilere yer verildikten sonra elde edilen veriler analiz edilmiştir. Elde edilen bulgulara göre, çalışanların psikolojik sermaye düzeylerinin örgütsel bağlılıklarını pozitif yönde etkilediği ortaya çıkmıştır.

\section{KAVRAMSAL ÇERÇEVE}

\subsection{Psikolojik Sermaye Kavramı ve Boyutları}

Psikolojik sermayenin temelini pozitif psikoloji ve pozitif örgütsel davranış yaklaşımları oluşturmaktadır. 20. yüzyılın ortalarından itibaren çalışanların pozitif yönleri üzerinde çeşitli araştırmalar yapılarak, kendilerini olumlu ve iyi hissettikleri yönlerini destekleyen ve gelişimlerini sağlayan uygulamalara geçilmiştir. Psikolojik sermaye kavramı da bu araştırmalar içerisinde yer alarak ilişkili olduğu konular 
üzerine çalışmalar yapılmaya başlanmıştır. Pozitif psikolojik sermaye kavramı ilk defa 2002 yılında Fred Luthans ve arkadaşları tarafından ortaya atılmıştır (Erkmen ve Esen, 2012:55).

Pozitif psikoloji, çalışanların problemlerine ya da sorunlarına değil, iyi taraflarına odaklanmaktadır. Psikolojik sermaye, çalışan verimliliğinin artışına olumlu yönde etki edecek bir dizi nitelik olarak tanımlanmaktadır (Aslan, 2017:5). Çalışanların kim olduğu ve psikolojik pozitif gelişimler ile neler elde edilebileceği konusunu kapsamaktadır (Kumlu, 2017:5). Günümüz örgütlerinde çalışanın daha fazla değerli olmaya başlaması ve örgütlerin çalışanı değerli hissettirme çabaları konuyu önemli hale getirmiştir.

Yaşananların olumlu yönde algılanması ve çalışanın bunu geliştirebilir görmesi psikolojik sermayenin alt yapısını oluşturmaktadır. Nelson ve Cooper'a (2007:11-14) göre psikolojik sermaye; beşeri ve sosyal sermayeden daha fazlasını ifade etmekte, pozitif yönlü, temelinde teori ve araştırmalardan elde edilen bilgiler bulunmakta, ölçülebilir, geliştirilebilir ve çalışanların verimliliği üzerinde etkilidir.

Psikolojik sermaye; zor çalışmalarla baş edebilmek için umudun var olması; başarılı olma beklentisi; uğraştırıcı hedeflerle mücadele edebilme; problemlerle ilgili çalışanın pozitif psikolojik durumudur (Avey, Wernsing ve Luthans, 2008: 54). Çalışanların verimli olmak amacıyla örgütsel ortamda başarılı olmaları için gereken yeteneklerinin önemine değinmektedir. Örgütlerin büyüme ve gelișim sürecini gerçekleştirebilmeleri için çalışanların performanslarını tam olarak göstermeleri gerektiği algısını ortaya koymaktadır (Luthans vd., 2008:210).

Luthans ve arkadaşları psikolojik sermayenin çeșitli boyutları olduğunu öne sürerek, bu boyutları öz yeterlilik, iyimselik, umut, psikolojik dayanıklılık olarak dört grupta kavramsallaștırmışlardır (Luthans vd., 2006:388):

1. Öz yeterlilik: Çalışanın zorlu görevleri başarmak için kendisine güvenebilmesi ve yeterli özgüvene sahip olması

2. İyimserlik: Çalışanın şimdi ve gelecekte başarılı olabileceğine dair iyimserlik duygusuna sahip olması

3. Umut: Çalışanın hedeflerine ulaşmada azimli olması ve yeni yollar deneyebilecek umuda sahip olması

4. Psikolojik dayanıklılık: Çalışanın güçlükler karşısında kalması durumunda toparlanabilmesi, güçlükler karşısında ısrarcı olması ve dayanıklılık göstermesi.

Psikolojik sermaye boyutlarından öz yeterlilik, Albert Bandura'nın (1982 ve 1997) Sosyal Bilişsel Teorisine dayanmakta olup, yapılan araştırmalar sonucunda geliştirilmiştir (aktaran Aslan, 2017:20). Öz yeterlilik boyutu, hedeflenen davranışları gerçekleștirmek üzere çalışanın yeteneklerine duyduğu güven düzeyini ifade etmektedir. Öz yeterlilik duygusuyla beraber çalışanların güçlü yönlerinin ortaya çıkarılmasının ve çalışanlar tarafından benimsenip geliştirilebilmesinin çalışanlarda kendilerine olan güven duygusunu da artıracağı belirtilmektedir. Öz yeterlilik düzeyleri artan çalışanların bașarıyı elde edeceklerine olan inanç ve azimleri artmaktadır (Avey, Wernsing ve Luthans, 2008: 54). Öz yeterlilik, belirli bir alana ve o alandaki çabalara yönelik olan çalışan inancıyla ilgili bir durumdur.

İyimserlik boyutu çalışanların olayları kendi açısından olumlu görmesi olarak değerlendirilmektedir. Çalışanın amacına ulaşmak için hayatta başına iyi şeylerin geleceğine dair genellenmiş bir beklenti olarak ifade edilmektedir (Keleş, 2012:347). Negatif olayları da kendisi dışında gerçekleşen, geçici ve olaylara özgü olarak yorumlamasıdır. İyimser insanlar, geçmişteki başarısızlıklara ve gerilemelere rağmen, pozitif beklentilerle ileriye doğru hareket etmeye devam ederler (Erkmen ve Esen, 2012:57). Gelecekle ilgili olumlu durumların ortaya çıkabileceğine dair bir beklenti söz konusudur. Araştırmalarda iyimser çalışanların, yaşamlarında daha çok çalışmaya teşvik edilebilen, daha kolay tatmin olabilen ve zorluklar karşısında pes etmeyen çalışanlar oldukları ifade edilmektedir.

Umut boyutu, belirli bir amaca ulaşmak için çalışanın pozitif beklentileri üzerinde durmaktadır. Çalışana özgü olan umut, gelecekle ilgili olasılıkları düşünerek esnek olabilme, farklı ihtimallere hazırlıklı olabilme, bu farklı ihtimaller içinde kendisine uygun olanı ayırt etme ve seçme durumlarını kapsamaktadır (Bruinink ve Bertram, 2005:330-331). Umut boyutunun iki önemli özelliği ortaya çıkmaktadır. Bunlardan birisi, hedefi elde etmeyi isteme ve hedefi elde edebilmek için kendinde güç hissetme iken; diğeri, hedefi elde edebilmek için yollar bulabilme becerisidir (Akman ve Korkut, 1993: 193-194).

Psikolojik dayanıklılık boyutu ise, çalışanların karșı karşıya oldukları riskli ve olumsuz durumlara karşı geliştirdikleri uyum ve olumlu tutum olarak ifade edilmektedir (Masten ve Reed, 2002: 119). Sikıntı, belirsizlik, çatışma, başarısızlık ve bunların yanında pozitif değişim, ilerleme ve artan sorumluluk karşısında harekete geçmedir (Erkmen ve Esen, 2012:57). Dayanıklılığın daha çok olumsuz olaylarda etkisini gösterdiği belirtilmekte, kavramın çalışma yaşamına özgü olumsuz koşul ve dönemlerinde çalışanın stresle başa çıkmasını kolaylaştıran bir özellik olduğu vurgulanmaktadır (Luthans, 2002, 61; Keleş:2012:348). 


\section{2. Örgütsel Bağlılık Kavramı ve Boyutları}

Örgütsel bağllığın hem çalışan hem de örgüt açısından beraberinde getirdiği katkılar bulunmaktadır. Örgütsel bağllık; örgütle uyum içerisinde çalıșma, zamanı ve enerjiyi örgütün başarısı için harcamada istekli davranış sergileme ve sorumlukları yerine getirme gibi konularda çalıșanları yönlendirmesi açısından önem arz etmektedir. Örgütsel bağlılık ilk olarak 1956 yllında Whyte tarafından araştırılmış, 1974'te Porter'in geliștirdiği ölçek ile ölçülmeye çalışılmıștır (Tutar, 2017:14).

Örgütsel bağlllık; çalışanın örgütün aktif bir üyesi olmaya devam etmeye istekli olmasıdır (Sökmen ve Şimşek, 2016:608). Porter ve Steers (1974) örgüt içindeki bağlılı̆̆ı, çalışanın varlı̆̆ı ile bütünleșebilecek bir güç ve bir örgüte dahil olmak olarak tanımlamışlardır (Arı vd., 2017:44).

Örgütsel bağlılık, çalışanın sadece işverenine sadakati olarak algılanmamalıdır. Örgütün yararına ve bașarısının sürmesi için çalıșanların düșüncelerini açıkladığı ve çaba gösterdikleri bir süreçtir. Örgütün kültürüne, örgütün kendisine ve kendisi dışındaki diğer bütün üyelerine olan sadakattir (Öztürk, 2013:10).

Örgütsel bağlılık, çalışanın örgüt amaç ve değerlerini kabul etmesi, bu amaçlara ulaşılması yönünde çaba sarf etmesi ve örgütte kalma durumunu devam ettirme arzusudur. Böylece örgütsel bağlllıkta temel olarak şu faktörler üzerinde durulmaktadır: 1) Örgütün amaç ve değerlerine gönülden inanıș ve bunları kabulleniş, 2) örgütten yana her şeyini ortaya koymaya gönüllü olma, 3) örgütün bir üyesi olarak kalma noktasında son derece güçlü bir irade ortaya koyma (Yüksel, 2000:176). Örgütsel bağllılı, çalışan ile örgüt arasında uyum, çalışan ve örgütün bir bütün olması, çalıșan ve örgütün amaçlarının birleşmesi, çalışan ve örgütün karșıllklı emeklerinin anlaşıldığına inanılması, çalışan ve örgütün karşllıklı sorumluluk hissetmesidir (Öztürk, 2013:11).

Yüksek örgütsel bağlılık çalışanın örgüte ait olma duygusunu arttırmakta ve örgüte yararlı olabileceği düşüncesi ile kendine hedefler oluşturmaktadır. Yüksek düzeyde bağllık gösteren çalışanların devamsızlıkları azaldığı ve ișten ayrılma niyetleri diğer çalıșanlara göre daha düșük olduğu ifade edilmektedir (Mowday vd., 1982: 139-140).

Örgütsel bağlılık, farklı araştırmacılar tarafından farklı boyutlara ayrılarak incelenmiștir. Mowday, Porter ve Steers, çalışanın davranışları vasıtasıyla görevlerine ve örgüte olan ilgisini güçlendiren inançlarına bağlanması şeklinde tanımlayarak, örgütsel bağlılığı davranışsal bağlılık ve tutumsal bağllılı olarak iki boyutta sınıflandırmıșlar. Çalıșanların örgütsel bağllılı düzeylerini 1974 yllında geliștirmiș ve örgütsel bağllı̆̆ğ 1979 yılında kullandıkları örgütsel bağlllık ölçeği ile ölçmüşlerdir (Azaklı, 2011:41-43). Davranışsal bağlılık, daha çok çalışanın geçmişteki davranışları nedeniyle örgüte bağlı kalma süresiyle ile ilgili iken; tutumsal bağlllık, çalışanın örgütsel amaçlarla özdeșleşmesi, örgütle bütünleșmesi ve bu doğrultuda çalışma istekliliği olarak ortaya çıkmaktadır. Dolayısıyla bu tür bir bağlılık, bireyin bazı manevi ödül ve menfaatler karșıllğı kendilerini örgüte bağladıkları bir alıș veriș ilișkisi olarak ifade edilmektedir (İlleez, 2012:20).

Yapılan araştırmalar içerisinde en çok kullanılan ve kabul gören modellerden birisi Allen ve Meyer'in geliștirdiği üç boyutlu örgütsel bağlllık modeli olmuștur. Meyer ve Allen (1991), literatürdeki tüm tanımların üç genel içerikten birini yansıttığını önererek, bu üç boyutu ortaya koymuşlardır. Bu boyutlar duygusal bağlılık, devam bağlllğıı ve normatif bağlılıktır.

Kaya'ya (2009) göre çalışanların örgüt üyeliğini sürdürmelerinin sebeplerden birisi duygusal bağlılıktır. Duygusal bağllık çalıșanların örgütleri ile bütünleșmesi ve kararlara dahil edilmesi sayesinde örgütüne karșı bağlılık hissetmesidir. Bu bağlılığı duyan çalıșan kendini ailenin bir ferdi olarak görmekte ve örgüt açısından kendisinin oldukça önemli olduğunu düşünmektedir (Kolancıoğlu, 2017:102).

Devam bağlılığı, çalışanın örgütten vazgeçmesiyle ilişkilendirdiği kayıplara dayanan bağlılığı içermektedir (Somuncu, 2008:49). Bu bağlılık, çalışanın seçeneklerinin bulunmaması ya da işsiz kalma riskine karşı örgütünün ona yüklediği güçlüklere katlanma ve dayanma mecburiyeti olarak tanımlanmıștır (Kolancıŏglu, 2017:104). Çalışan mevcut işinden ayrıldığında karşılaşacağı maddi ve manevi zorlukları düșünüp, işyerine katlanması gerektiğini kabul ederek mecburi olarak bağlılık duyması șeklinde ifade edilebilir.

Normatif bağlılık, çalışanın örgütte kalması için zorunluluk hissetmesini içermektedir (Allen ve Meyer, 1990:18). Bu zorunluluk hissi, çalıșanın ahlaki duygularıyla ve inandıkları değerlerle ilgilidir. Çalıșan, örgütün kendisini ve bağlılığını hak ettiğini düşünmektedir.

Her üç boyut da çalışanların örgüt içinde devam etme isteklerinin esas unsur olduğu görülmektedir (Özdevecioğlu, 2003:114). Her üç bağllılı boyutunda çalışanla örgüt arasında bir bağ oluşmaktadır, ancak boyuta göre bağllığın niteliği farklılık göstermektedir. Duygusal bağlılıkta çalışan istediği için, devam 
bağlılı̆̆ında ihtiyacı olduğu için, normatif bağllıkta da öyle olması gerektiğine inandığı için çalışan örgütüne bağlılık duymaktadır (Allen ve Meyer, 1991:3). Duygusal bağlılıkta çalışanın isteği önemliyken, devam bağllıkta zorunluluk hissi, normatif bağlllıkta yükümlülük duyguları devreye girmektedir.

\section{LITERATÜR TARAMASI}

Literatüre bakıldığında, psikolojik sermaye ve örgütsel bağlılık üzerine yapılan inceleme ve araştırmaların sayısının artırılması gerektiği söylenebilir. Psikolojik sermaye ile örgütsel bağlılık konuları ile ilgili bugüne kadar yapılan araştırma ve uygulamalar incelenmiş ve özetlenmeye çalışılmıştır.

Aslan (2017), Şırnak ilinde görev yapan 608 öğretmenden oluşan örneklem üzerinde araştırma yaparak, öğretmenlerin pozitif psikolojik sermaye algıları ile örgütsel bağlılıkları arasındaki ilişkiye bakmış ve düşük düzeyde pozitif yönde anlamlı bir ilişkinin olduğu sonucuna ulaşmıştır. Öğretmenlerin pozitif psikolojik sermaye algısının örgütsel bağlılığı az da olsa etkilediği sonucuna ulaşılmıștır. Çalışmada öğretmenlerin pozitif psikolojik sermayenin alt boyutlarına ilişkin algılarının örgütsel bağlılığın duygusal ve normatif bağlılık alt boyutları için modelin anlamlı olduğu görülürken, devam bağlılığı boyutuna ilişkin model için bir farklılığa rastlanmamıştır. Araştırmanın sonucunda pozitif psikolojik sermayenin örgütsel bağlılığı pozitif yönde etkilediği sonucuna varılmıştır.

Lifeng'in (2007) Çin'de 198 yönetici ile yapmıș olduğu araştırma sonucunda psikolojik sermayenin umut, iyimserlik ve psikolojik dayanıklılık boyutlarının ayrı ayrı ve bu üç boyutun bir bütün olarak, örgütsel bağlılık üzerinde etkisi olduğunu ortaya koymuştur. Yine Luthans ve Jensen (2005) çalışmalarını hemşireler üzerinde yapmış ve psikolojik sermaye ile örgütsel bağlllık arasında pozitif yönlü bir ilişki bulmuştur.

Şen, Mert ve Aydın, Ankara ve Malatya'da faaliyet gösteren kamu ve ilgili kuruluşlarında çalışan 298 çalışandan elde ettikleri veriler ile ulaştıkları sonuçlardan birisi de psikolojik sermayenin örgütsel bağlılık ile pozitif ilișkili olduklarıdır.

Yan ve Lingli (2011)'nin araştırmalarını Çin'de faaliyet gösteren WISCO şirketinde uygulamışlardır. Araştırma hipotezlerinden birisi psikolojik sermaye ile iş performansı arasındaki ilişkide örgütsel bağlılığın ilişkisi olmuş; psikolojik sermayenin iş performansını etkilemesi konusunda örgütsel bağlılı̆̆ın kısmi aracılık etkisi olduğunu ortaya koymuşlardır.

Kaya'nın 2012 yılında çalışmasında uygulama yeri olarak Konya ilindeki kamu üniversite hastanelerinde çalışan hemşireleri seçmiş ve 205 hemşireden veri elde etmişlerdir. Verilerle psikolojik sermaye ile mesleki bağlılık ilişkisi incelenmiş; umut boyutu ile normatif bağllık arasında; dayanıklılık boyutu ile de devam bağllı̆̆ı arasında, iyimserlik boyutu ile duygusal ve normatif bağllık arasında pozitif ilişki bulunmuştur.

Güler (2016)'in çalışması, pozitif psikolojik sermaye ve bileșenleri ile örgütsel bağlllık ve boyutları arasında anlamlı ilişski olup olmadığını perakende sektörü çalışanları üzerinde inceleyen ilk araştırmadır. Büyük bir alışveriş merkezinde giyim kategorisinde faaliyet gösteren mağazalarda çalışan 175 kişiden anket toplanmıştır. Analiz sonuçlarına göre; pozitif psikolojik sermaye bileşenleri ile duygusal bağlılık ve devam bağlılı̆̆ı arasında anlamlı bir ilişkinin olduğu görülmüştür. Pozitif psikolojik sermayenin dayanıklılık boyutu ile örgütsel bağlılığın normatif bağlılık boyutu arasında anlamlı bir ilişki bulunmuştur. Ancak iyimserlik, umut ve öz yeterlilik boyutları ile normatif bağlılık arasında anlamlı bir ilişki bulunamamıștır.

Ocak ve arkadaşları (2016) Bosna'da görev yapan 215 Bosnalı öğretmen üzerine yaptıkları analizleri sonucunda örgütsel psikolojik sermayenin sadece iyimserlik alt boyutunun iş tatmini ve örgütsel bağlllık üzerinde olumlu etkilerinin olduğu bulgusuna ulaşmışlardır. Bir başka araştırmada ise, etkileşimsel adalet ile örgütsel bağlılık arasında anlamlı ve pozitif bir ilişki olup olmadığı ve psikolojik sermayenin bu ilişkide aracılık etkisi tespit edilmeye çalışılmış, analiz sonuçlarının pozitif olduğu ancak zayıf bir ilişki varlığı ile psikolojik sermayenin bu ilişki üzerinde tam aracılık etkisi olduğu ortaya konmuştur (Çoban, 2013:27).

Genç 2014 yılındaki çalışmasında, Ankara'daki kamu kurumlarında 309 çalışandan elde ettiği bulgularla psikolojik dayanıklılığın örgütsel bağlılık ve işten ayrılma niyetine etkisinin bireysel ve sosyal koşullar ile ilişkili faktörlerin ekseninde geliştiğini ortaya koymuştur.

Bu araştırma kapsamında oluşturulan hipotezler ve model şu şekildedir:

H1: Psikolojik sermaye boyutlarının kamu çalışanlarının örgütsel bağlılığı üzerinde anlamlı bir etkisi vardir.

H1(a): Psikolojik sermayenin öz yeterlilik boyutunun kamu çalışanlarının örgütsel bağlılı̆̆ üzerinde anlamlı ve pozitif bir etkisi vardır. 
H1(b): Psikolojik sermayenin iyimserlik boyutunun kamu çalışanlarının örgütsel bağlılığı üzerinde anlamlı ve pozitif bir etkisi vardır.

H1(c): Psikolojik sermayenin umut boyutunun kamu çalışanlarının örgütsel bağlılı̆̆ üzerinde anlamlı ve pozitif bir etkisi vardır.

H1(d): Psikolojik sermayenin psikolojik dayanıklılık boyutunun kamu çalışanlarının örgütsel bağlılığı üzerinde anlamlı ve pozitif bir etkisi vardır.

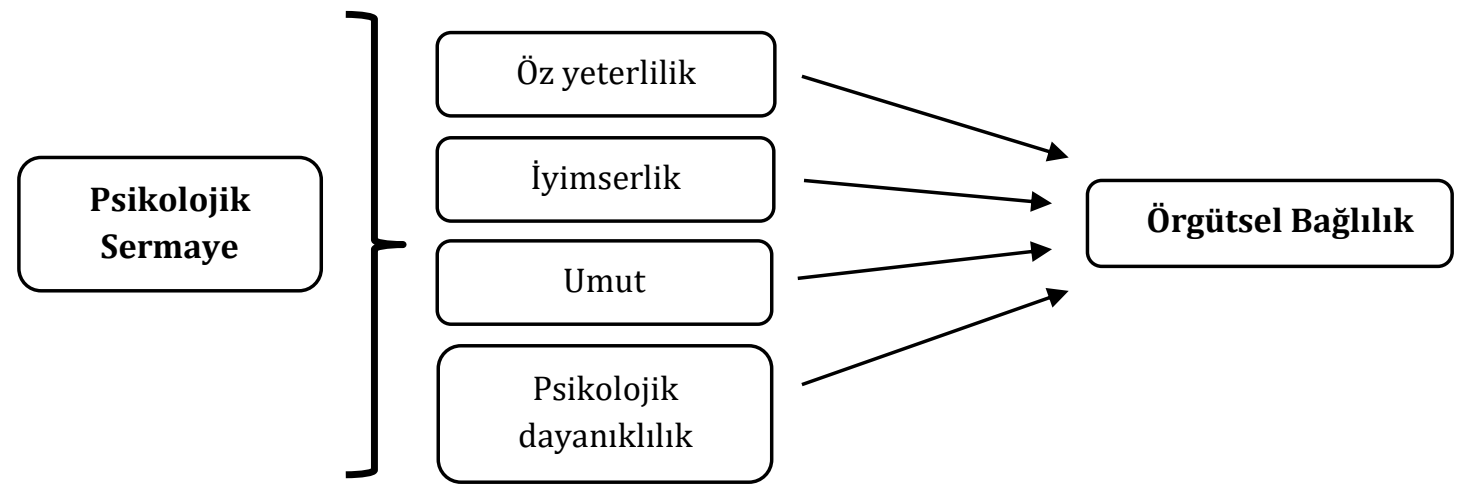

\section{YÖNTEM}

\section{1. Örneklem}

Araştırma yapılan kurum, merkezi Ankara'da bulunan ve tarım ve hayvancılık alanlarında faaliyet gösteren bir kamu kurumudur. Bir kamu kurumunun vatandaşlara verdiği hizmetler sebebiyle sektörler arası işleyişlerin aksamaması sebebiyle, çalışanlarının psikolojik sermaye düzeylerinin güçlü, örgüte bağlılıklarının da yüksek olması gerektiği düşünülmektedir. Verilere ulaşmanın kolaylığı açısından uygulama, kurumun Kütahya ve Kütahya'ya yakın illerinde (Afyonkarahisar, Ankara, Denizli) gerçekleştirilmiştir.

Araştırma yapılacak illerde çalıșan personel sayısı toplam 271 kişidir. Evrenin özelliklerini yansıtması düşüncesiyle seçilen örneklem grubu, basit tesadüfi örneklem yolu ile oluşturulmuştur. Ankete her ilden eşit sayıda kişi katılmasına özen gösterilmiştir. Toplam alarak 200 kişi örnekleme dahil edilmiştir. Anketlere doğru ve zamanında katılım gerçekleştiren 157 kişi olmuştur. İllerden elde edilen veri sayısı Kütahya'dan 38 kişi, Denizli'den 42 kişi, Ankara'dan 45 kişi ve Afyonkarahisar'dan 32 kişidir.

Araştırmaya katılanlar ile ilgili demografik özellikler Tablo 1'de yer almaktadır:

Tablo 1: Katılımcllarla İlgili Demografik Bilgiler

\begin{tabular}{lll|lll}
\hline Öğrenim Durumları & Frekans & Yüzde (\%) & Medeni Durum & Frekans & Yüzde (\%) \\
\hline Kadın & 78 & 49,7 & Bekar & 60 & 38,2 \\
Erkek & 79 & 50,3 & Evli & 91 & 58 \\
& & & Diğer & 6 & 3,2 \\
\hline Öğrenim Durumu & Frekans & Yüzde (\%) & Yaş & Frekans & Yüzde (\%) \\
\hline İlköğretim & 6 & 3,8 & $18-24$ & 18 & 11,5 \\
Lise & 30 & 19,1 & $25-30$ & 36 & 22,9 \\
Önlisans & 12 & 7,6 & $31-38$ & 55 & 35 \\
Lisans & 79 & 50,3 & $39-45$ & 30 & 19,1 \\
Yükseklisans & 18 & 11,5 & 46 ve üzeri & 18 & 11,5 \\
Doktora & 12 & 7,6 & & & \\
\hline İșletmede çalışma süresi & Frekans & Yüzde (\%) & İş hayatında çalışma süresi & Frekans & Yüzde (\%) \\
\hline 1 yıldan az & 6 & 3,8 & 1 yıldan az & 6 & 3,8 \\
$1-3$ yıl arası & 36 & 22,9 & $1-3$ yıl arası & 12 & 7,6 \\
4-6 yıl arası & 36 & 22,9 & $4-6$ yıl arası & 24 & 15,3 \\
7-9 yıl arası & 67 & 42,7 & $7-9$ yıl arası & 48 & 30,6 \\
10 yıl ve üzeri & 12 & 7,6 & 10 yıl ve üzeri & 67 & 42,7 \\
\hline
\end{tabular}


Katılım sağlayanlarda kadın ve erkek oranı birbirine yakındır. Katılımcıların çoğunluğu; evli, üniversite mezunu, 31-38 yaş aralığındadır. Araştırma yapılan kurumda çalışma sürelerine bakıldığında 7 ile 9 yıl arası çalışan sayısı fazladır. Çalışanların çoğunluğu ise 10 yıldan daha uzun bir süredir çalışma hayatında yer almaktadir.

\section{2. Ölçüm Araçları}

$\mathrm{Bu}$ çalışmada veri toplama aracı olarak anket yöntemi tercih edilmiştir. Anket formu hazırlanırken psikolojik sermaye ve örgütsel bağlılık konularında sık kullanılan ölçekler taranmıștır. Araştırmada Mowday, Steers ve Porter (1979) tarafından geliștirilmiş olan "örgütsel bağlılık" ölçeği tercih edilmiştir. Anketin Türkçe versiyonu İleez'in (2012) "Örgüt İkliminin İşgörenlerin Örgütsel Bağlılıklarına Etkisi: Konaklama İşletmelerinde Bir Uygulama” başlıklı çalışmadan elde edilmiştir. İlgili çalışma içerisinde güvenilirlik analizi sonucu Alpha değeri 0.775 bulunmuştur. Ölçekte 15 madde yer almaktadır. Ölçekte "Bu kurumdaki görevimi büyük ölçüde parasal kaygılarla yapıyorum”, "Bu kurumda çalışmaya karar vermekle büyük ölçüde hata ettiğimi düşünüyorum", "Emek ve birikimlerim bu kurumdan ayrılmamı engelliyor" gibi ifadeler yer almaktadır.

Pozitif psikolojik sermaye ölçeği için Luthans ve arkadaşlarının (2007) geliştirdiği 24 sorudan oluşan "Psikolojik Sermaye Ölçeği" kullanılmıștır. Ölçekte psikolojik sermayenin "öz yeterlilik", "umut", "iyimserlik" ve "psikolojik dayanıklılık" boyutlarını ölçen 24 soru yer almaktadır. Sorular ölçeği Türkçe'ye uyarlayan Çetin ve Basım'ın (2012) araştırmasından alınmıştır. Öz yeterlilik 1, 9, 11, 14, 18, 19; iyimserlik $3,4,15,16,21,23$; psikolojik dayanıklılık 5, 7, 8, 10, 13, 22 ve umut 2, 6, 12, 17, 20, 24 sorularla ölçülmektedir. Boyutlar için yapılan güvenilirlik analizleri sonucunda hesaplanan Alpha değerleri sırasıyla $0.89,0.89,0.89$ ve 0.88 'dir. Ölçekte "Yaptığım işlerin tüm aşamalarında kendimden eminimdir", "Kendime güvenirim", "Başarı için yapmam gerekeni biliyorum" gibi ifadeler yer almaktadır. Araştırmadaki ölçeklerde “1: Kesinlikle Katılmıyorum” ve “5: Kesinlikle Katılıyorum” şeklinde 5’li Likert Ölçeği kullanılmıştır.

Araştırmada kullanılan ölçekleri daha önce Türkçe’ye uyarlayan çalışmalarda doğrulayıcı faktör analizi yapılmıştır. Psikolojik sermaye ölçeği için, Çetin ve Basım (2012)’ın çalışmasında yaptıkları doğrulayıcı faktör analizinde en iyi uyum değerlerini dört boyutlu yapının sağladığı ortaya çıkmıştır $(\chi 2 / \mathrm{df}=2,18$; RMSEA=0,057; CFI=0,90). Örgütsel bağlılık ölçeği için, Sarıkaya (2018) çalışmasında yaptığı doğrulayıcı faktör analizinde modelin uyum iyiliği indekslerini $\chi 2 / \mathrm{df}=2,521$; RMSEA=0,061 olarak bulmuş ve elde ettiği bulgulara göre hem kullanılan ölçeklerin yapısal geçerliliği hem de etki modelinin istenilen kriterleri sağladığını ifade etmiştir. Örgütsel bağlılık ölçeği maddelerinin ait oldukları ölçeğe etkileri incelendiğinde, bütün maddelerin etkilerinin istatistiksel olarak anlamlı olduğunu ifade etmiștir.

Araştırmada model için kabul edilebilir bir uyumdan bahsedebilmek ve uyum indekslerini görmek için SPSS Amos 25.0 istatistik programı kullanılmıștır. Uyum indeksi değeri, ki-kare değerinin serbestlik derecesine bölünmesiyle elde edilmektedir. Bu oranın iki veya ikinin altında bir değere eşit olması modelin iyi bir model olduğunu; beş veya daha altında bir değere eşit olması da modelin kabul edilebilir bir uyum iyiliğine sahip olduğunu göstermektedir (Erkorkmaz ve diğ., 2013:213). Araştırmada ele alınan modelde bahsedilen değerlerin 5'in altında çıkması kabul edilebilir bir uyumu göstermektedir. Diğer indeks değerleri de kabul edilebilir değerler aralığında yer almaktadır (uyum iyiliği indeksinin-GFI0,90'dan, düzeltilmiş uyum iyiliği indeksinin-AGFI- 0,80'den, karşılaştırmalı uyum indeksinin-CFI0,90'dan büyük olması, hata tahminlerinin kareköklerinin ortalamasının-RMSEA- 0,05 ve altında olmasıiyi uyum ya da 0,08'in altında olması-kabul edilebilir uyuma işaret etmektedir). Modele ilişkin uyum indeksleri değerleri Tablo 2'de gösterilmektedir:

Tablo 2: Modele İlişkin Uyum İndeksleri Değerleri

\begin{tabular}{|l|c|c|c|c|c|}
\hline & Örgütsel Bağlılık & Öz yeterlilik & Umut & İyimserlik & $\begin{array}{c}\text { Psikolojik } \\
\text { Dayanıklılık }\end{array}$ \\
\hline $\boldsymbol{\Delta \mathbf { X } ^ { 2 } / \mathbf { D f }}$ & 2,54 & 2,78 & 3,10 & 2,12 & 1,83 \\
\hline GFI & 0,91 & 0,90 & 0,98 & 0,90 & 0,92 \\
\hline AGFI & 0,81 & 0,92 & 0,83 & 0,98 & 0,91 \\
\hline CFI & 0,91 & 1 & 0,90 & 1 & 0,92 \\
\hline RMSEA & 0,07 & 0,38 & 0,78 & 0,74 & 0,71 \\
\hline
\end{tabular}

$\mathrm{p}<.001$.

Araştırmada kullanılan ölçeklerin güvenilirlik boyutunun araştırılması amacıyla ölçeklerin Cronbach Alpha katsayıları hesaplanmıștır. Örgütsel bağlılık soruları için bulunan Alpha değeri 0.934 iken, 
psikolojik sermaye boyutlarından öz yeterlilik, iyimserlik, psikolojik dayanıklılık ve umut soruları için bulunan Alpha değerleri sirasiyla 0.746, 0.962, 0.818 ve 0.952'dir. Bu değerler ölçeklerin tümünün güvenilirlik katsayılarının kabul edilebilir olduğunu göstermektedir.

\section{BULGULAR}

Veriler, SPSS Statistics 24.0 istatistik paket programında analiz edilmiştir. Verilerin analizine başlamadan önce, verilerin normal dağılım gösterip göstermediklerine bakılmıștır. Ölçeklerin Shapiro-Wilk testine göre sig. değerleri 0,05 'ten büyük olduğundan verilerin normal dağılım gösterdiği anlașılmaktadır. Normalliğe iliş̧in çarpıklık (skewness) ve basıklık (kurtosis) değerlerinin de -1.5 ve +1.5 arasında kaldığı görülmektedir. Ölçeklerin normallik analizi sonuçları Tablo 3'te yer almaktadır. Veriler normal dağılım gösterdiği için analize parametrik testlerle devam edilmiştir.

Tablo 3: Ölçeklerin Normallik Analizi Sonuçları

\begin{tabular}{|l|c|c|}
\hline \multicolumn{1}{|c|}{ Değişkenler } & Çarpıklık & Basıklık \\
\hline Öz Yeterlilik &,- 863 &,- 025 \\
\hline İyimserlik & $-1,383$ & 1,110 \\
\hline Psikolojik Dayanıklılık & $-1,131$ & 1,365 \\
\hline Umut & $-1,316$ &, 781 \\
\hline Örgütsel Bağlılık & $-1,180$ & 1,356 \\
\hline
\end{tabular}

Oluşturulan hipotezleri test etmek için önce değişkenler arasındaki Pearson korelasyon katsayılarına bakılmıștır. Elde edilen sonuçlar Tablo 4'de yer almaktadır. Bu sonuçlar, psikolojik sermaye boyutları ile örgütsel bağllık arasında anlamlı ve pozitif yönlü bir ilişkinin olduğunu göstermektedir $(p<0.01)$. Değerlerin 0,6'dan büyük olması değișkenler arasında yüksek korelasyon olduğunu göstermektedir. Değişkenler arasındaki pozitif yönlü ilişkinin varlığı iki değişkenin birlikte değiștiğini göstermektedir (Gürbüz ve Şahin, 2014). Değişkenlerden birisi artarken diğeri de artmaktadır.

Tablo 4: Korelasyon Analizi Sonuçları

\begin{tabular}{|c|c|c|c|c|}
\hline \multirow{2}{*}{ Bağımlı Değişken } & \multicolumn{4}{|c|}{ Bağımsız Değişkenler } \\
\cline { 2 - 5 } & Öz Yeterlilik & İyimserlik & $\begin{array}{c}\text { Psikolojik } \\
\text { Dayanıklılık }\end{array}$ & Umut \\
\hline Örgütsel Bağlılık & $0,880^{* *}$ & $0,879^{* *}$ & $0,793^{* *}$ & $0,913^{* *}$ \\
\hline ** $\mathrm{p}=<0.01$ (2-tailed).
\end{tabular}

Değişkenler arasındaki iliş̧kiye bakıldıktan sonra, araştırma kapsamında esas soru olan bağımsız değişkenlerin bağımlı değişkeni etkileyip etkilemediğini test etmek amacıyla regresyon analizi yapılmıştır. Regresyon analizi bağımlı değişkenin diğer bağımsız değişkenler tarafından nasıl açıklandığını belirlemeye çalışmaktadır. Ancak regresyon analizinden önce veri setinin analizin varsayımlarını karşılayıp karşılamadığını belirlemek amacıyla, çoklu doğrusal bağlantı araştırılmıştır. Çoklu doğrusal bağlantı, bağımsız değişkenler arasında ilişki olmaması durumunu göstermektedir. VIF değeri 10'a eşit veya daha büyükse anlamlı çoklu doğrusal bağlantı probleminden söz edilmektedir (Vupa ve Gürünlü Alma, 2008:99). Modelde yer alan bağımsız değerlerin VIF değerlerinin 10'dan düşük çıkması çoklu doğrusal bağlantı probleminin olmadığını ifade etmektedir. Bağımsız değişkenlere ilişkin hesaplanan VIF değerleri Tablo 5'te yer almaktadır:

Tablo 5: Çoklu Doğrusal Bağlantı Sonuçları

\begin{tabular}{|c|c|c|c|c|}
\hline Değişkenler & Öz Yeterlilik & İyimserlik & $\begin{array}{c}\text { Psikolojik } \\
\text { Dayanılılık }\end{array}$ & Umut \\
\hline VIF değerleri & 7,025 & 9,081 & 4,112 & 8,708 \\
\hline
\end{tabular}

Hipotezde birden fazla bağımsız değişken olmasından dolayı çoklu doğrusal regresyon analizi yapılmıştır. Regresyon analizi sonuçları istatistiksel olarak anlamlıdır (Foz yeterlilik=529,99; Fiyimserlik=524,61; Fdayanıklılık=261,861; Fumut=777,47 p<0.001). Regresyon analizi sonuçları Tablo 6'da yer almaktadır: 
Tablo 6: Regresyon Analizi Sonuçları

Psikolojik Sermaye Boyutlarının Örgütsel Bağlılığa Etkisi

\begin{tabular}{|l|l|l|l|l|}
\hline Bağımlı Değişken & \multicolumn{4}{|c|}{ Bağımsız Değişkenler } \\
\hline & \multicolumn{1}{|c|}{ Öz Yeterlilik } & \multicolumn{1}{|c|}{ İyimserlik } & $\begin{array}{c}\text { Psikolojik } \\
\text { Dayanıklılık }\end{array}$ & \multicolumn{1}{|c|}{ Umut } \\
\cline { 2 - 5 } & $\beta=0,880$ & $\beta=0,879$ & $\beta=0,793$ & $\beta=0,913$ \\
\cline { 2 - 5 } Örgütsel Bağlılık & $\mathrm{F}=529,99$ & $\mathrm{~F}=524,61$ & $\mathrm{~F}=261,861$ & $\mathrm{~F}=777,47$ \\
\cline { 2 - 5 } & $\mathrm{R}^{2}=0,774$ & $\mathrm{R}^{2}=0,772$ & $\mathrm{R}^{2}=0,628$ & $\mathrm{R}^{2}=0,834$ \\
\cline { 2 - 5 } & $\mathrm{B}=0,911$ & $\mathrm{~B}=0,703$ & $\mathrm{~B}=0,750$ & $\mathrm{~B}=0,714$ \\
\cline { 2 - 5 } & $\mathrm{p}=, 000^{\mathrm{b}}$ & $\mathrm{p}=, 000^{\mathrm{b}}$ & $\mathrm{p}=, 000^{\mathrm{b}}$ & $\mathrm{p}=, 000^{\mathrm{b}}$ \\
\hline
\end{tabular}

Tabloya bakıldığında öz yeterlilik boyutundaki 1 birim artıș örgütsel bağlllı̆̆ 0,880 birim; iyimserlik boyutundaki 1 birim artıș örgütsel bağglılı̆̆ 0,879 birim; psikolojik dayanıklılık boyutundaki 1 birim artıș örgütsel bağlılı̆̆ı 0,793 birim; umut boyutundaki 1 birim artış örgütsel bağlılı̆̆ı 0,879 birim artırmaktadır.

Analizin düzeltilmiş $\mathrm{R}^{2}$ değerlerine bakıldığında; öz yeterlilik boyutu örgütsel bağlılığı \%77'lik varyans (değişim) ile, iyimserlik boyutu örgütsel bağlllığı \%77'lik varyans ile, psikolojik dayanıklılık boyutu örgütsel bağllı̆̆ı \%63'lük varyans ile, umut boyutu örgütsel bağlılığı \%71'lik varyans ile açıklamaktadır. Varyans yüzdelerinin yüksek olması güçlü ve pozitif yönde anlamlı bir etki olduğunu göstermektedir.

Tüm analiz sonuçları değerlendirildiğinde regresyon modeli anlamlıdır ve oluşturulan " $\mathrm{H}_{1}$ : Psikolojik sermaye boyutlarının kamu çalışanlarının örgütsel bağlılı̆̆ üzerinde anlamlı bir etkisi vardır" hipotezi ve alt hipotezler kabul edilmektedir. Psikolojik sermaye boyutları örgütsel bağlllı̆̆ı pozitif yönde etkilemektedir.

\section{SONUÇ ve TARTIȘMA}

Araştırmada çalışanların psikolojik sermaye düzeylerinin örgütsel bağlllıklarına olan etkisini ortaya konmak amaçlanmıștır. Bu etki araştırılırken psikolojik sermaye kavramının alt boyutları olarak tanımlanan iyimserlik, psikolojik dayanıklılık, umut ve öz yeterlilik boyutlarının örgütsel bağlılığa olan etkileri ayrı ayrı analiz edilmiștir.

Analiz sonuçlarına göre, psikolojik sermaye boyutlarının örgütsel bağllığı etkilediği sonucuna ulaşılmıştır. Araştırma sonuçlarının, Aslan'ın (2017) Şırnak ilinde görev yapan 608 öğretmenden oluşan örneklem üzerinde yaptığı araştırma sonucu ile ulaştığı pozitif psikolojik sermayenin örgütsel bağlılı̆̆ı pozitif yönde etkilediği sonucu ile uyumlu olduğu görülmektedir. Her iki çalışma da kamu alanında faaliyet gösteren kurumlarında uygulanmıştır. Aslan'ın çalışmasının doğu illerinden birinde, bu çalışmanın ise batı illerinden bazılarında yapılmasına rağmen benzer sonuçları vermesinin önemli olduğu düşünülmektedir.

Lifeng'in (2007) Çin'de 198 yönetici ile yapmıș olduğu araștırma sonucunda ortaya koyduğu psikolojik sermayenin umut, iyimserlik ve dayanıklılık boyutlarının ayrı ayrı örgütsel bağllık üzerinde etkisi olduğu bulgusu yapılan araştırmamızla desteklenmektedir. Lifeng'in araştırması sadece yöneticiler üzerinde uygulanmıştır. Bu çalışmada ise mavi ya da beyaz yaka şeklinde bir ayrıma gidilmemiştir. Luthans ve Jensen (2005) çalıșmalarını hemșireler üzerinde yapmıș ve psikolojik sermaye ile örgütsel bağlllık arasında pozitif yönlü bir ilișki bulmuștur. Kaya'nın (2012) çalıșmasında uygulama yeri olarak Konya ilindeki kamu üniversite hastanelerinde çalışan hemşireleri seçmiş, örgütsel bağlılık boyutları da analize dahil edilmiş ve 205 hemşireden elde ettiği veriler sonucunda umut boyutu ile normatif bağlılık arasında; dayanıklılık boyutu ile de devam bağlılığı arasında, iyimserlik boyutu ile duygusal ve normatif bağlılık arasında pozitif ilişki bulunmuştur. Psikolojik sermaye boyutlarının örgütsel bağlılığa etkisi konusunu ortaya koyması açısından önem arz etmektedir. Yine Kaya'nın çalışması da araștırmamız gibi kamu alanında gerçekleştirilmiştir.

Güler (2016)'in çalışması, psikolojik sermaye ve bileşenleri ile örgütsel bağlılık ve boyutları arasındaki ilișkiyi perakende sektörü çalıșanları üzerinde inceleyen ilk araștırma olması sebebiyle dikkat çekicidir. Büyük bir alışveriş merkezinde giyim kategorisinde faaliyet gösteren mağazalardan 175 kişiden veri toplanarak yaptığı analizlerden bağlılığı etkileyen sonuçlar elde etmiştir. Güler'in araştırması araştırmamızdan farklı olarak özel sektörde uygulanmış ve çalışmamızla uyumlu olarak yorumlanmıştır.

Ancak araştırmamızın sonuçları, Ocak ve diğ. (2016)'nin 215 Bosnalı öğretmenler üzerine yaptıkları araştırma sonucunda ifade ettikleri örgütsel psikolojik sermayenin sadece iyimserlik alt boyutunun örgütsel bağlllık üzerinde olumlu etkilerinin olduğu bulgusu ile çelişmektedir. Ocak ve diğ.'nin 
araştırmasının örnekleminin sadece belirli bir bölgede yaşayan öğretmenleri kapsaması sebebiyle bu farklı sonuca vardıkları düşünülmektedir.

Yaşananların olumlu yönde algılanması ve çalıșanın bunu geliștirebilir görmesi psikolojik sermayenin temelini oluşturmaktadır. Kavramsal çerçevede de belirtildiği üzere, psikolojik sermaye çalıșanların verimli olmak amacıyla örgütsel ortamda başarılı olmaları için gereken yeteneklerinin önemine değinmektedir. Örgütsel bağlllık da örgütle uyum içerisinde çalışma, örgütün başarısı için istekli olma ve sorumlukları yerine getirme gibi konularda çalışanları yönlendirmesi açısından önemli bir konudur. Psikolojik sermayenin boyutları olarak öne sürülen öz yeterlilik, iyimserlik, psikolojik dayanıklılık ve umut duygularına sahip çalışanların örgütsel bağlllıklarının etkileneceklerini düşünülerek araştırma gerçekleştirilmiştir. Elde edilen veriler ve bulgular, çalışanlarının örgüte bağlılığını artırmak isteyen örgütlerin psikolojik sermaye boyutlarına önem vermeleri gerektiğini vurgulamaktadır.

Çalışanların örgüte olan bağlılıklarını artırmak ve örgütte devamlılı̆ını sağlamak isteyen örgütlerin çalışanların psikolojik sermaye düzeyini yükselterek çalışanlarına uygun çalışma koşulları yaratması, çalışanların gelişimlerini destekleyen eğitim olanaklarını artırması ve onları desteklemesi, örgüt ve çalışan için ulaşılabilir hedefler belirlemesi, örgüt içi iletişimi sağlıklı hale getirmesi, uygun koşullarda çalışanın kararlara katılımını destekleyerek ve örgüte güveni artırarak çalışanın örgüt içinde kalmaya istekli olmasını sağlamaları gerekmektedir. Kamusal alanda faaliyet gösteren bir kurum, çalışanına sunacağı imkanlar konusunda bir özel firma gibi hızlı hareket edemeyebilir, kaynaklarını gerekli izinleri almadan yöneticinin yönlendirdiği şekilde kullanamayabilir, çalışanların alabilecekleri terfiler konusunda engellerle karşılaşllabilir. Bu durumlar kamu kurumunun işinin daha da zor olduğunu göstermektedir. Ancak kamu alanında çalışanlara tanınan haklar ve izinler fırsata dönüştürülebilir. Kurumun kendi içerisinde oluşturacağı örgüt kültürü ve iletişim sayesinde psikolojik sermaye ve örgütsel bağlılık konularına yönelebileceği ve geliștirebileceği düşünülmektedir.

Literatürde psikolojik sermaye boyutlarının örgütsel bağlllık ile olan ilişkisine dair çalışmalar mevcuttur. $\mathrm{Bu}$ çalışmanın kamu alanında bir uygulama olması sebebiyle ilgili literatüre katkı sağlaması beklenmektedir. Çalışmamız sadece kamu alanında faaliyet gösteren bir kurumda gerçekleştirilmiştir. Özel sektörde bir uygulama yapılarak, kamu ve özel sektörlerde çalışanların bağllıkları ölçülerek, farklılıkları ortaya koyan bir araştırmanın gerçekleştirilebileceği düşünülmektedir. Çalışmamız için analize dahil edilen veriler Kütahya ve çevresindeki iller ile kısıtlı kalmıștır. Diğer illerin de araştırmaya dahil edilebileceği daha kapsamlı bir araştırma gerçekleştirilebilir. Araştırma belirli bir zaman kesitinde neden ve sonuç arasındaki ilișkinin birlikte incelendiği araștırma olması sebebiyle kesitsel bir araştırmadır. Neden-sonuç iliş̧isi aynı zaman kesitinde birlikte incelenmiştir. Ayrıca sadece yöneticilerin örnekleme alınarak, psikolojik sermaye boyutlarının örgüte bağllıklarını etkileyip etkilemediği değerlendirilebilir. Çalışmamızda örgütsel bağllık boyutlarına kavramsal olarak değinilmiş ancak analiz kısmında boyutlar ayrı ayrı araştırmaya dahil edilmemiştir. Örgütsel bağlılık boyutları da ayrı ayrı ele alınarak, duygusal, devam ve normatif bağlılığın psikolojik sermaye boyutları ile ilişkisi analiz edilebilir. 


\section{KAYNAKÇA}

Akman, Y. ve Korkut, F. (1993), "Umut Ölçeği Üzerine Bir Çalışma", H. Ü. Eğitim Fakültesi Dergisi, 9, 193202.

Allen, N. J. ve Meyer, J. P. (1990), "The Measurement and Antecedents of Affective, Continuance and Normative Commitment to the Organization", Journal of Occupational Psychology, 63( 1), 1-18.

Allen, N. J. ve Meyer, J. P. (1991), "A Three-Component Conceptualization of Organizational Commitment" , Human Resource Management Review, 1(1), 61-89.

Arı, M., Altın, Gülova A. ve Köse, S. (2017), "Örgütsel Adalet Algısı ile Örgütsel Bağlılık Davranışının İlişkisi: Bir Sağlık Kuruluşunda Araştırma”, Dokuz Eylül Üniversitesi Hemşirelik Fakültesi Elektronik Dergisi, 10(1), 43-51.

Aslan, İ. (2017), "Öğretmenlerin Pozitif Psikolojik Sermaye Algıları İle Örgütsel Bağlılıkları Arasındaki İlişkinin İncelenmesi", Yüksek Lisans Tezi, Siirt Üniversitesi, Siirt.

Avey, J. B., Wernsing, T. S. ve Luthans, F. (2008), “Can Positive Employees Help Positive Organizational Change? Impact of Psychological Capital and Emotions on Relevant Attitudes and Behaviors", Journal of Applied Behavioral Science, 44(1), 48-70.

Azaklı, Ö. (2011), "CCalışanların Örgüte Bağllıkları ve İş Güvencesizliği Algısı ile İșten Ayrılma Niyeti Arasındaki İlişkinin İncelenmesine Yönelik Bir Uygulama”, Yüksek Lisans Tezi, Yıldız Teknik Üniversitesi, İstanbul.

Bruininks, P. ve Bertram, F. M. (2005), "Distinguishing Hope From Optimism and Related Affective States", Motivation and Emotion, 29(4), 327-355.

Çetin, F., ve Basım, H.N. (2012), “Örgütsel Psikolojik Sermaye: Bir Ölçek Uyarlama”, Çalışması Amme İdaresi Dergisi, 45(1), 121-137.

Çoban, A. (2013), "Psikolojik Sermayenin Örgütsel Adalet ve Örgütsel Bağlllık İlişkisi Üzerindeki Rolü", Organizasyon ve Yönetim Bilimleri Dergisi, 5, 2, ISSN: 1309 -8039 (Online).

Ergüner Tekinalp, B. ve Işık Terzi, Ş. (2015). Eğitimde Pozitif Psikoloji Uygulamaları, Pegem Akademi, Ankara.

Erkmen, T. ve Esen, E. (2012), "Bilişim Sektöründe Çalışanların Psikolojik Sermaye Düzeylerinin Belirlenmesine Yönelik Bir Araştırma”, Afyon Kocatepe Üniversitesi İ̈BF Dergisi, 14(2), 55-72.

Erkorkmaz, Ü., Etikan, İ., Demir, O., Özdamar, K. ve Sanisoğlu, S. Y. (2013), "Doğrulayıcı Faktör Analizi ve Uyum İndeksleri", Türkiye Klinikleri Med Sci, 33(1), 210-223.

Erkuş, A., Turunç, Ö. ve Yücel, R. (2011). “Örgütsel Adalet ve Örgütsel Bağlllık Arasındaki İlişkilerde İçsel ve Dişsal İş Tatmininin Aracılık Rolü: Bankacılık Sektöründe Bir Araştırma”, Eskişsehir Osmangazi Üniversitesi İIBF Dergisi, 6(1), 245-270.

Eryılmaz, A. (2013), “Pozitif Psikolojinin Psikolojik Danışmanlık ve Rehberlik Alanında Gelişimsel ve Önleyici Hizmetler Bağlamında Kullanılması", The Journal of Happiness \& Well-Being, 1(1), 1-22.

Fredrickson, B. L. (2001), "The Role of Positive Emotions in Positive Psychology: The Broaden-And-Build Theory of Positive Emotions", American Psychologist, 56, 218-226.

Genç, A. (2014), "Psikolojik Dayanıklılığın Örgütsel Bağlılık ve İşten Ayrılma Niyetine Etkisi: Görgül Bir Araştırma", Yüksek Lisans Tezi, Başkent Üniversitesi, Ankara.

Güler, G. (2016), "Pozitif Psikolojik Sermaye İle Örgütsel Bağlllık İlişkisi: Mersin İli Perakende Sektörü Çalışanları Üzerine Bir Araştırma", Yüksek Lisans Tezi, Toros Üniversitesi, Mersin.

İlleez, Z. (2012), “Örgüt İkliminin İşgörenlerin Örgütsel Bağlllıklarına Etkisi: Konaklama İşletmelerinde Bir Uygulama", Yüksek Lisans Tezi, Gazi Üniversitesi, Ankara.

Kaya, D. Ş. (2012), "Psikolojik Sermaye ve Mesleki Bağllık İlişkisine Kariyer Planlamasının Etkilerinin Belirlenmesine Yönelik Bir Model Önerisi", Yüksek Lisans Tezi, Selçuk Üniversitesi, Konya.

Keleș, H.N. (2011), "Pozitif Psikolojik Sermaye: Tanımı, Bileșenleri ve Örgüt Yönetimine Etkileri", Organizasyon ve Yönetim Bilimleri Dergisi, 3, 2, ISSN: 1309 -8039 (Online).

Kolancıoğlu, B. (2017), “Örgüt Kültürünün Örgütsel Bağlllık Üzerindeki Etkisi ve Bir Uygulama”, Yüksek Lisans Tezi, İstanbul Ticaret Üniversitesi, İstanbul. 
Kumlu, T. (2017), "Otel İşletmesi Çalışanlarının Pozitif Psikolojik Sermaye Düzeyleri İle Örgütsel Vatandaşlık Davranışları Arasındaki İliş̧i”, Yüksek Lisans Tezi, Çanakkale Onsekiz Mart Üniversitesi, Çanakkale.

Küçük, T. (2015), “Kamu İlkokullarında Görevli Öğretmenlerin Örgütsel Bağlllık Düzeyleri Diyarbakır İli Örneği”, Yüksek Lisans Tezi, Zirve Üniversitesi, Gaziantep.

Lifeng, Z. (2007), “Effects of Psychological Capital on Employees' Job Performance, Organizational Commitment, and Organizational Citizenship Behavior", Acta Psychologica Sinica, 2, 18.

Luthans, F., Avey, J. B. ve Patera, J. L. (2008), "Experimental Analysis of a Webbased Training Intervention to Develop Positive Psychological Capital", Academy of Management Learning\&Education, 7(2), 209-221.

Luthans, F., J. B. Avey, Avolio, B. J., Norman S. M. ve Combs G. M. (2006), "Psychological Capital Development: Toward a Micro-Intervention", Journal of Organizational Behaviour, 27, 387-393.

Luthans, Fred. (2002), "Positive Organizational Behavior: Developing and Managing Psychological Strengths", Academy of Management Executive, 16, 57-72.

Luthans, K.W. ve Jensen, S.M. (2005), "The Linkage Between Psychological Capital and Commitment to Organizational Mission: A Study of Nurses", Journal of Nursing Administration, 35(6), 304-310.

Masten, A. S. ve Reed, M. J. (2002), Resilience in Development. In C. R. Snyder, \& S. J. Lopez (Eds.), Handbook of Positive Psychology, New York: Oxford University Press.

Mowday, R., Porter, L., Steers, R. ve Warr, P. (1982), Employee-Organization Linkages: The Psychology of Commitment. Absenteeism and Turnover, Londra: Academic Press.

Nelson, D. ve Cooper, C.L. (2007), Positive Organizational Behavior, London: Sage Publication.

Ocak M., Güler M. ve Basim H. N. (2016), "Psikolojik Sermayenin Örgütsel Bağlılık ve İș Tatmini Tutumları Üzerine Etkisi: Bosnalı Öğretmenler Üzerine Bir Araştırma”, Çankırı Karatekin Üniversitesi İktisadi ve İdari Bilimler Fakültesi Dergisi, 6(1), 113-130.

Özdevecioğlu, M. (2003), "Algılanan Örgütsel Destek ile Örgütsel Bağlılık Arasındaki İlişkilerin Belirlenmesine Yönelik Bir Araştırma", Dokuz Eylül Üniversitesi İ.I.B.F. Dergisi, 18(2), 113-130.

Özmen, A. (1999), Sosyal Bilimlerde Araștırma Yöntemleri, Ed. Ali Atıf Bir. Eskişehir: T.C. Anadolu Üniversitesi Yayınları No: 1081.

Öztürk, M. (2013), “Örgütsel Bağllık ve Sağlık Çalışanlarının Örgütsel Bağlllık Düzeyleri (Kırklareli Örneği)", Yüksek Lisans Tezi, Beykent Üniversitesi, İstanbul.

Sarıkaya, G.S. (2018), “İşgören Kaygı Düzeyinin Örgütsel Adalet AlgıSı İle Örgütsel Bağlılık İlişkisinde Aracılık Rolü: Yiyecek İçecek İşletmeleri Örneği”, Yüksek Lisans Tezi, Gazi Üniversitesi, Ankara.

Somuncu, F. (2008), "Örgütsel Bağlılık ve Örgütsel Bağllığı Geliştirme Araçları: Özel Bir Hizmet İşletmesinde Araştırma", Yüksek Lisans Tezi, Anadolu Üniversitesi, Eskişehir.

Sökmen, A. ve Tuğçe, Ș. (2016), "Örgütsel Bağllık, Örgütle Özdeșleșme, Stres ve İșten Ayrılma Niyeti İlişkisi: Bir Kamu Kurumunda Araștırma", Gazi Üniversitesi Íktisadi ve İdari Bilimler Fakültesi Dergisi, 18(3), 606-620.

Şen C., Mert, İ. S. ve Aydın, O. (2017), “The Effects of Positive Psychological Capital on Employee's Job Satisfaction, Organızational Commitment, and Ability Coping With Stress", Journal of Academic Research in Economics, 9(2), 164-184.

Tutar, H. N. G. (2017), "İşyerindeki Yıldırma Davranışlarının İșten Ayrılma Niyeti Üzerindeki Etkisi: Örgütsel Bağllılı ve Örgütsel Sessizliğin Aracıllk Rolü”, Yüksek Lisans Tezi, Mustafa Kemal Üniversitesi, Hatay.

Vupa, Ö. ve Gürünlü Alma, Ö. (2008), "Doğrusal Regresyon Çözümlemesinde Çoklu Bağlantı Probleminin Sapan Değer İçeren Küçük Örneklemlerde İncelenmesi", S. Ü. Fen Edebiyat Fakültesi Fen Dergisi, 31, 97107.

Yan, Z. ve Lingli, Z. (2011), "Research on the Relationship between Psychological Capital and Job Performance in WISCO", https://ieeexplore.ieee.org/document/5881370, (15.10.2018). 